\title{
READING THE OLD TESTAMENT IN POSTMODERN TIMES
}

\author{
Craig Bartholomew
}

\begin{abstract}
Summary
This article explores the impact of postmodernism on Old Testament studies by looking at the recent proposals of Rendtorff, Brueggemann and Clines. Rendtorff discerns a crisis in Old Testament studies with the demise of the Wellhausenian paradigm. He argues for a methodological pluralism in the present. Brueggemann stresses the epistemological shift that postmodernism entails and argues for a hermeneutic that funds postmodern imagination. Clines welcomes the pluralism of postmodernism and articulates a consumer hermeneutic while favouring ideological critique of the Bible. This article argues that some form of metanarrative shaping one's hermeneutic is inevitable and that at its best postmodernism re-opens the debate about a religiously shaped hermeneutic.
\end{abstract}

\section{Introduction}

In virtually every discipline there is a growing body of 'postmodernity and...' literature. Old Testament studies is no exception. Central to the postmodern turn is a crisis of the philosophical foundations of modernity, ${ }^{1}$ and these philosophical tremors are being felt throughout the academy, not least in biblical studies. Thus Anthony Thiselton writes:

These perspectives constitute the most serious and urgent challenge to theology, in comparison with which the oldstyle attacks from 'common-sense positivism' appear relatively naïve. Theology has more at stake than perhaps any other discipline because, although philosophy and some other disciplines share the same loss of truth, theology

\footnotetext{
1See C.G. Bartholomew, 'Post/Late? Modernity as the Context for Christian Scholarship Today', Themelios 22.2 (1997) 25-38
} 
serves to establish critically-informed trust, whereas the postmodern perspective rests on suspicion. ${ }^{2}$

For the past two hundred years the extent to which biblical studies should share the 'trust' of theology has been controversial. It became commonplace in the university to assume that biblical exegesis should take place in isolation from theology and that it should not be related to Scriptural proclamation. Francis Watson ${ }^{3}$ refers to C.F. Evans' proposal that we should strive 'to ensure as far as possible that exegesis is studied in such a way that it does not issue in proclamation.' This rigid drawing of boundaries between exegesis, theology and proclamation is now open to question in ways that it was not some twenty years ago. Either way, however, postmodernism represents a crisis for biblical studies, casting aspersion, as it does, upon all metanarratives, whether theological or secular modernistic. 4

In this exploratory paper we examine three major Old Testament scholars, Rolf Rendtorff, Walter Brueggemann and David Clines, who work, respectively, in Germany, North America and England, as they wrestle with the postmodern turn and its implications for Old Testament studies. The aim is not to survey scholars' views of post-modernism comprehensively but to probe the significance of postmodernism for Old Testament studies through the positions of three scholars who are actively addressing the issues postmodernism raises.

2Interpreting God and the Postmodern Self. On Meaning, Manipulation and Promise (Edinburgh: T. \& T. Clark, 1995) 16.

${ }^{3}$ Text, Church and World. Biblical Interpretation in Theological Perspective (Edinburgh: T. \& T. Clark, 1994) 6.

${ }^{4} \mathrm{~J}$. Lyotard's understanding of postmodernity as 'incredulity towards metanarratives' is well known (The Postmodern Condition. A Report on Knowledge [Manchester: Manchester UP, 1984]). There is some debate about whether or not the Christian story is strictly speaking a metanarrative, and one should, I think, distinguish the Christian story from a conceptually tight metaphysic. However, generally postmodern thinkers lump theology together with metanarratives, so that even if one should make this distinction, the point is that they do not! See A. Walker, Telling the Story. Gospel, Mission and Culture (London: SPCK, 1996) 4-5. 


\section{Rendtorff: Diagnosing the Crisis}

\section{The Demise of the Wellhausen Paradigm}

In his forward to Rendtorff's Canon and Theology Brueggemann rightly describes Rendtorff as a German scholar who is 'pivotal for the next wave of Old Testament scholarship.' 5 A student of Von Rad, Rendtorff is an heir of that hugely influential German tradition of scholarship embodied in the work of Von Rad, Zimmerli, Noth, etc. However, he is one of relatively few German scholars to see the limitations of historical criticism and to pursue canonical and theological readings of the Old Testament. We will focus in particular upon Rendtorff's assessment of the current state of biblical scholarship in his article 'The Paradigm is Changing: Hopes-and Fears.' 6

If the postmodern condition is characterised by flux, change, instability and crisis as Harvey ${ }^{7}$ suggests then, according to Rendtorff, this is certainly true of contemporary Old Testament hermeneutics. Rendtorff maintains that

Old Testament scholarship at present is 'in crisis'. The Wellhausen paradigm no longer functions as a commonly accepted presupposition for Old Testament exegesis. And at present, no other concept is visible that could replace such a widely accepted position... the shaking of this paradigm is part of a far-reaching shaking of the centuries-old fundamentals of Old Testament scholarship... Almost half a thousand years have faded away. ${ }^{8}$

Rendtorff follows Kuhn' in using 'paradigm' to refer to a methodological model that has secured consensus in a discipline so that scholarly work in that discipline is practised within the framework established by that paradigm. According

${ }^{5} \mathrm{~W}$. Brueggemann, 'Foreword', in R. Rendtorff, Canon and Theology. Overtures to an Old Testament Theology (Edinburgh: T. \& T. Clark, 1993) vii.

${ }^{6}$ Biblical Interpretation 1/1 (1993) 34-53.

${ }^{7} \mathrm{D}$. Harvey, The Condition of Postmodernity. An Enquiry into the Origins of Cultural Change (Oxford: Blackwell, 1989).

${ }^{8}$ Rendtorff, 'The Paradigm is Changing', 44.

${ }^{9} \mathrm{~T}$. Kuhn, The Structure of Scientific Revolutions (Chicago: University of Chicago Press, 19702). 
to Rendtorff this is precisely what has happened in Old Testament study this century. Wellhausen's documentary hypothesis has been the paradigm within which Old Testament scholarship has operated, but is now being widely questioned.

Rendtorff rightly perceives the growing fragmentation and diversity in Old Testament studies today. One only has to glance at the variety of hermeneutical approaches in operation to confirm this. Not all may agree that there is a crisis, but as Rendtorff perceptively notes,

If we follow his [Kuhn's] analysis, we must expect that, for a longer or shorter period, some old Testament scholars will not recognise the symptoms of crisis at all, or will not be prepared to recognise them. Instead they will expect that solutions to the problems can be found through an ever more rigorous and even more precise application of the old methods. ${ }^{10}$

However it is questionable whether the undermining of the Wellhausen paradigm is a sufficient analysis of the crisis. Indeed Rendtorff uses the notion of paradigm in a somewhat contradictory way. On the one hand he argues that the Wellhausen paradigm dominates Old Testament scholarship during this century, but simultaneously sees Gunkel, Von Rad and Noth as undermining this paradigm. Thus he writes:

I have sought to demonstrate that Old Testament scholarship in this century was, and still is, deeply determined by the methods of Literarkritik, in the form of the Documentary hypothesis. At the same time, this paradigm was continually undermined by form criticism and its continuation in tradition criticism and, in a certain sense, in redaction criticism-a development that finally led to a new interest in the final form of books, and even larger entities, within the Old Testament. ${ }^{11}$

For Rendtorff the significant difference between Wellhausen and Gunkel/Von Rad/Noth is the latter's concern with the oral

${ }^{10}$ Canon and Theology, 180.

11'The Paradigm is Changing', 43. 
history of the material underlying the text. Although Gunkel, Von Rad and Noth maintained Wellhausen's sources-this indicates for Rendtorff the existence and strength of the Wellhausen paradigm-their research actually led in a different direction. Rendtorff implies that this direction is towards contemporary focus on the final form of the text.

There is a link between some of Von Rad's creative exegesis (for example on Genesis), redaction criticism, and final form readings of the text. ${ }^{12}$ However a narrative of Gunkel's work leading on to final form readings today is too simplistic, as Rendtorff himself recognises. ${ }^{13}$ Form criticism has more in common with source criticism in its concern with reconstructing earlier stages of texts. Rendtorff is concerned to establish continuity between historical criticism and contemporary readings of the Old Testament and consequently a narrative of continuity fits his purposes. It fails, however, to do justice to the strong reaction to modernity that is at the heart of postmodernity and which underlies the crisis in Old Testament studies today.

To understand the present crisis in Old Testament studies it is vital to penetrate behind Wellhausen's source criticism and Gunkel's form criticism to discern the common matrix out of which both scholars worked. Rendtorff implies as much when he says that the crisis has shattered the edifice of half a millennium of Old Testament scholarship. Indeed if Gunkel could so easily introduce a different paradigm, then it is difficult to see how one could continue to call Wellhausen's documentary hypothesis a paradigm at all; it is much better seen as a dominant manifestation of a paradigm. Rendtorff's analysis, I suggest, does not take sufficient account of the fact that the worldview of modernity underlies both approaches.

\footnotetext{
12 Von Rad, for example, was involved in the formation of Interpretation, a journal which is committed to hearing the message of the Old Testament texts as redactional wholes.

${ }^{13}$ There is a continuity with the present discussion about the final shape of the text, canon criticism and the like... But I think it would be an inappropriate harmonization of the history of research to draw too strong a line from Gunkel through von Rad and Noth to the present discussion, because there are obvious elements of discontinuity, in particular since the mid-seventies' ('The Paradigm is Changing', 43).
} 
Rendtorff recognises that Wellhausen was deeply influenced by romanticism but does not pursue the issue of philosophical shaping in discerning the dominant paradigm operative in twentieth century scholarship. ${ }^{14}$ However, as Nicholson and many others recognise, the historical critical method has its roots in Enlightenment philosophies of history, and it is as the philosophical presuppositions of modernity have been shaken that historical criticism too has inevitably come under suspicion. 15

\section{A Solution? Methodological Pluralism}

Rendtorff is sure that the dominant Wellhausen paradigm has ended: 'I do not see any new arguments that could turn back the wheel.' What has changed, he says, is not the object of study: 'the sources are the same as they have always been. What has changed is the scholarly attitude to the sources, in particular to the main core of sources, namely the texts of the Old Testament itself.'16 In looking at changing attitudes towards the Old Testament and history Rendtorff notes the tendency to try and write histories of Israel without the Old Testament. He dislikes this tendency and even more the tendency of those engaged in such ventures to declare their method the only right one and those who pursue more traditional approaches biblicists or fundamentalists.

There are many scholarly approaches and methods, in Bible studies as well as in history writing. Nobody will forbid any scholar or group or school to believe their own method to be the best one. Many will be interested in seeing the results and checking their validity and usefulness. But in scholarship there is by definition no heresy. We should rather practice and accept methodological pluralism. ${ }^{17}$

The great advantage in the newer literary methods is, according to Rendtorff, their concern with the text as it is. For too long Old Testament scholarship has neglected the final form of texts.

\footnotetext{
${ }^{14}$ 'The Paradigm is Changing', 35.

${ }^{15} \mathrm{E}$. Nicholson, Interpreting the Old Testament. A Century of the Oriel Professorship (Oxford: Clarendon, 1981).

${ }^{16}$ 'The Paradigm is Changing', 44-46.

${ }^{17}$ 'The Paradigm is Changing', 47 ; italics mine.
} 
'Scholars still seem to be proud of knowing things better than the final redactors or compilers. This is a kind of nineteenthcentury hubris we should have left behind us.'18 And indeed, Rendtorff has been at the forefront in Germany in promoting canonical and theological readings of Old Testament texts and the renewal of biblical theology. ${ }^{19}$ Rendtorff concludes:

The paradigm is changing. I believe it has changed already. But the field is open. Many new and fruitful approaches are visible that will lead Old Testament scholarship into the twenty-first century. At the moment there is no new model that could be expected to achieve common acceptance as a paradigm, and there will probably be none in the near future. ${ }^{20}$

One senses that for Rendtorff methodological pluralism is a way of establishing continuity between historical criticism and contemporary methods of reading the Old Testament, and preventing an unhealthy absolutisation of new methods of interpretation. What he does not perhaps take adequate account of is the ideological exclusivism that permeated historical criticism. Now that the boot is on the other foot it is too easy to make a plea for methodological pluralism.

Rendtorff correctly recognises that Old Testament studies is increasingly characterised by fragmentation and pluralism; common postmodern themes. But it is not just that the Wellhausen paradigm has lost its power, as Rendtorff correctly asserts, but that the underpinnings of the dominant mode of Old Testament interpretation in modernity seem to many no longer valid. The postmodern turn has called modernity into question: since the dominant method of Old Testament interpretation in modernity, historical criticism, is deeply rooted in the modern world view, it is inevitable that historical criticism should also partake of the crisis of modernity. It is this link that Rendtorff has not explored in his analysis of the contemporary crisis in Old Testament studies, and consequently he too easily speaks of continuity between

18'The Paradigm is Changing', 52.

${ }^{19}$ See Rendtorff's Canon and Theology.

${ }^{20}$ 'The Paradigm is Changing', 52-53. 
the historical critical era and the 'postmodern era' in Old Testament interpretation, and too easily imagines that a methodological pluralism will solve the situation. Not that there is no continuity: but the crisis is philosophical as well as methodological, with different epistemologies competing for attention. Rendtorff rightly recognises that 'the use of new methods does not make the old questions disappear. We have to ask whether or to what extent the questions posed by traditional Old Testament scholarship have been legitimate and of what relevance they are in a changed framework.'21 But frameworks are more than methods: they are the philosophical and epistemological underpinnings of methods, and in this respect Rendtorff's solution is, I suspect, in danger of replacing an exclusive modernistic method-historical criticism-with a (liberal) model of pluralism which may not facilitate the emergence of alternative, unified frameworks.

Just how different the new epistemological situation potentially is, is clear from Brueggemann's description of the new postmodern context in which Old Testament studies must now be done. ${ }^{22} \mathrm{He}$ asserts that we are now in a situation where:

(i) Our knowing is inherently contextual. Who and what we are, what communities we belong to, these elements are always involved in our Old Testament interpretation. Scholarship without 'prejudice', to use Gadamer's term, is not possible. So called neutral historical critical scholarship was deeply prejudiced in its own ways, something which the myth of neutrality sought to conceal.

(ii) Contexts are quite local so that it is impossible to 'voice large truth'. Brueggemann here articulates Lyotard's view that the present situation is one of 'incredulity towards metanarratives': it was particularly the metanarratives of modernity that Lyotard was wary of.

(iii) Knowledge is inherently pluralistic. 'Indeed, pluralism is the only alternative to objectivism once the

${ }^{21}$ Rendtorff, Canon and Theology, 28.

${ }^{22} \mathrm{~W}$. Brueggemann, The Bible and Postmodern Imagination. Texts Under Negotiation (London: SCM, 1993) 8-11. 
dominant center is no longer able to impose its view and to silence by force all alternative or dissenting opinion.'23

Rendtorff has taken up the third issue of pluralism but has not dealt with the first two, or perhaps one should say he has done a surface analysis of pluralism but not a depth one. The crisis is bigger than he realises. The problem is, as we have said, not just one of methodological pluralism but of philosophical (epistemological) pluralism. The implication of this is that no single paradigm can claim to be the obvious one: each must now give an account of itself. If Old Testament scholars continue to labour under the banner of neutral historical criticism or propose the sort of methodological pluralism that Rendtorff does, they will need to account for their use of this particular epistemology in Old Testament studies. ${ }^{24}$

Brueggemann and Clines are more perceptive analysts of the postmodern situation. We will examine their approaches to develop our analysis of the postmodern situation and to see how they propose Old Testament studies be reshaped in this new situation.

\section{Brueggemann: Funding Postmodern Imagination}

Brueggemann has long insisted on the role of imagination in biblical interpretation. ${ }^{25}$ However, only recently in The Bible

${ }^{23}$ The Bible and Postmodern Imagination, 9.

${ }^{24}$ Cf. J.D. Levenson, The Hebrew Bible, the Old Testament and Historical Criticism (Louisville: Westminster/John Knox, 1993) 109-110: 'the very value-neutrality of [historical criticism] puts its practitioners at a loss to defend the value of the enterprise itself. In a culture saturated with religious belief involving the Bible, this weakness was less apparent, for the defence was less called for. Now, however, after secularism has impugned the worth of the Bible, and multiculturalism has begun to critique the cultural traditions at the base of which it stands, biblical scholars, including, I must stress, even the most antireligious among them, must face this paradoxical reality: the vitality of their rather untraditional discipline has historically depended upon the vitality of traditional religious communities, Jewish and Christian... When fundamentalists become liberals... the need for an affirmation that goes beyond mere historical description does not evaporate.'

25See for example his The Prophetic Imagination (Philadelphia: Fortress, 1978); see also L.G. Perdue, The Collapse of History. Reconstructing Old 
and Postmodern Imagination has he outlined in more detail his understanding of imagination and related imagination to the postmodern situation. This is not to suggest that Postmodern Imagination signals a radical shift in Brueggemann's thinking; rather he uses postmodern theorising to validate and develop his previous work on imagination and Old Testament theology.

Brueggemann emphasises the change in our epistemological context signified by the postmodern turn. According to him, we are in 'a wholly new interpretative situation'. ${ }^{26}$ 'What is now required and permitted is a mode of scripture interpretation quite unlike most of what we have practised heretofore.' 27 The metanarrative of modernity is a construct which is no longer credible or relevant. Historical criticism has been shaped by this construct and shares in its crisis:

It is my judgement that church interpretation (especially where historical criticism has been taken with excessive seriousness) has tended to trim and domesticate the text not only to accommodate regnant modes of knowledge, but also to enhance regnant modes of power. ${ }^{28}$

Historical criticism is built on an epistemology which privileges neutral rationality and this is no longer acceptable. Brueggemann proposes an epistemology which privileges imagination, which he defines as 'that operation of receiving, processing, and ordering that transpires when my mind wonders in listening to a text, a reading, in praying, or in any other time.'29 For Brueggemann imagination refers to:

the human capacity to picture, portray, receive, and practice the world in ways other than it appears to be at first glance when seen through a dominant, habitual, unexamined lens. More succinctly, imagination as the quintessential human act is a valid way of knowing. Imagination as a human act does not yield the kind of certitude required by Cartesian

Testament Theology (Minneapolis: Fortress, 1994) 285-98 for a description of Brueggemann's work prior to The Bible and Postmodern Imagination.

26Brueggemann, The Bible and Postmodern Imagination, vii.

27The Bible and Postmodern Imagination, 64.

${ }^{28}$ The Bible and Postmodern Imagination, vii.

${ }^{29}$ The Bible and Postmodern Imagination, 62. 
anxiety, but it does yield a possible 'home' when we accept a participating role as 'home-maker'. ${ }^{30}$

We thus need a mode of reading the Bible which funds postmodern imagination. This does not involve constructing a full new metanarrative but interpreting the Old Testament in such a way as to provide the pieces out of which a new world can be imagined. Brueggemann sees the main context for this as the church community and envisions 'a place where people come to receive new materials, or old materials freshly voiced, that will fund, feed, nurture, nourish, legitimate, and authorize a counter imagination of the world.'31

The Christian community is privileged as the context of interpretation. Brueggemann stresses that in our postmodern context all worldviews are under negotiation so that

Reality... is no longer a fixed arrangement inhospitable to theological categories, but is an ongoing, creative, constitutive task in which imagination of a quite specific kind has a crucial role to play. The core of our new awareness is that the world we have taken for granted... is an imaginative construal. And if it is a construal, then from any other perspective, the world can yet be construed differently. It is the claim of our faith, and the warrant of our ministry, to insist that our peculiar memory in faith provides the materials out of which an alternatively construed world can be properly imagined. ${ }^{32}$

Faith thus plays a central role in Brueggemann's hermeneutic of postmodern imagination. Although he is very wary of imposing systematic categories upon texts he does want to take the Bible seriously as the Word of God and proposes an evangelical infrastructure of memory, covenant and hope to shape interpretation. Furthermore he includes liturgy, preaching and teaching in the enterprise of biblical interpretation.

Brueggemann proposes a dramatic model of biblical interpretation in which reality is taken as a drama and the

${ }^{30}$ The Bible and Postmodern Imagination, 13.

31 The Bible and Postmodern Imagination, 20.

32The Bible and Postmodern Imagination, 17-18. 
biblical text as a script for the drama. This model evokes playful open-endedness which is appropriate to our present liminality, and avoids the modern dangers of conservative retreat into propositional absolutes on the one hand, and liberal developmentalism on the other. Such an approach will be strongly text-centred, applying itself to one text at a time. Creation/fall/redemption may be the core drama of the Bible but Brueggemann, although sympathetic to the work of Lindbeck and Frei, is wary of privileging this drama at the expense of the small stories of the Bible. The individual text must be allowed to speak in all its roughness so that it can do its task of subverting our assumed world. In this way the Bible will function as the 'compost pile that provides material for new life.' ${ }^{33}$ There is little room for historical criticism in this method, and the aesthetisising of the new literary criticism also needs to be guarded against. The Bible is treated as an 'army of metaphors' with which the listener is called to actively engage.

\section{Clines: Old Testament Consumerism}

David Clines is one of the most capable, creative and wideranging Old Testament scholars in the UK today. Currently he is a strong proponent of a postmodern approach to the Old Testament and we shall focus on him in this capacity. His current position is clearly articulated in his 1993 article, 'Possibilities and Priorities of Biblical Interpretation in an International Perspective.'34 In respect of his current methodological position he also gave a lecture in Cheltenham in December 1994 titled 'Shopping for Methods in Biblical Studies These Days'. We will use these sources and some of his most recent publications to outline his present position. This is in my opinion best described as 'Old Testament consumerism.' 35

${ }^{33}$ The Bible and Postmodern Imagination, 61.

${ }^{34}$ D.J.A. Clines, 'Possibilities and Priorities of Biblical Interpretation in an International Perspective', Biblical Interpretation 1/1 (1993) 67-87.

${ }^{35}$ See also D.J.A. Clines, Interested Parties: The Ideology of Writers and Readers of the Hebrew Bible (Sheffield: Sheffield Academic Press, 1995). 
Clines stresses the actual and, in his opinion, desirable pluralism in Old Testament studies nowadays. He used to think that Old Testament scholars were all doing the same thing in their scholarship but now he realises that different scholars have different goals. The Bible, furthermore, is a common cultural object and biblical interpretation must make room for the religious and ideological plurality of our societies. It is important for Clines to be able to affirm that the Bible is not just an ecclesiastical object but a cultural one: 'my academic context has no connections whatsoever with the church... It is not, therefore, surprising that what I want to affirm is that the Bible is a cultural artefact in our society, and not just an ecclesiastical object.' 36 A tension thus exists between the church and biblical studies in the academy and Clines considers this healthy. Although in today's economic climate biblical scholars are having to produce products that will sell,

academic freedom has to mean-not a freedom to research their subject in isolation from the impact their work has on anyone except their fellow academics, but-freedom to choose their own priorities and goals, freedom to resist the magisterium of anyone-church leaders, politicians, and also the senior scholars who distribute research grantsfreedom to resist the imposition of the agenda of anyone at all. ${ }^{37}$

It is good for the church to be challenged by the less powerful academy:

The church does not really know, I think, how much it needs to be liberated from the shackles of fundamentalism, or how much it needs to abandon the use of the Bible as a tool for social control... The academy's biblical criticism inevitably relativizes the authority of the Bible, and the church can only benefit from such a humanizing of the Bible. 38

36Clines, 'Possibilities and Priorities', 76.

37'Possibilities and Priorities', 77.

38'Possibilities and Priorities', 77-78. 
The pluralism in Old Testament studies is related to the recognition nowadays that all interpretation is contextual and cultural. In Clines' view one constructs one's identity out of one's prejudices and presuppositions and it would be a mistake to suppress these in interpretation. This, combined with the postmodern break with Cartesian categories makes for a deeply pluralist situation, but in Anglo-American biblical studies,

the full impact of the contemporary break with the Cartesian categories has still to register... most active scholars still write as if they were engaged in a quest for objectively determinable meanings and objectively verifiable history. The shifting of the ground brought about by the philosophical hermeneutics of Gadamer or the deconstructive philosophy of Derrida is bound to bring questions of method to the forefront in biblical and theological studies. ${ }^{39}$

\section{A Consumer Product}

In response to our changed context Clines proposes an enduser theory of interpretation. He says: 40

I want to propose a model for biblical interpretation that accepts the realities of our pluralist context... First comes the recognition that texts do not have determinate meanings... The second axis for my framework is provided by the idea of interpretative communities... There is no objective standard by which we can know whether one interpretation or other is right; we can only tell whether it has been accepted... There are no determinate meanings and there are no universally agreed upon legitimate interpretations.

What are biblical scholars then to be doing with themselves? To whom shall they appeal for their authorisation, from where shall they gain approval for their activities, and above all, who will pay them?... If there are no 'right' interpretations, and no validity in interpretation beyond the assent of various interest groups, biblical interpreters have to give up the goal of determinate and universally acceptable interpretations, and devote

39'Possibilities and Priorities', 75.

40'Possibilities and Priorities', 78-80. 
themselves to interpretations they can sell-in whatever mode is called for by the communities they choose to serve. I call this 'customised' interpretation.

Such an end-user approach could entail recycling old waste interpretations which were thought to have been superseded by the progress model of modernity. Now these discarded interpretations could be revived in a post-critical form to stock afresh the shelves of the interpretational supermarket.

\section{Ideological Critique}

Clines goes on to say that he regards the literary turn in Old Testament studies as the most important trend since the middle of this century, with its focus upon the text in its final form as a literary artefact, upon the reader and her role in the construction of meaning and upon hermeneutics and the nature of language and texts. Clines particularly commends feminist and ideology criticism. Feminist criticism more than any other form relativises the authority of the Bible because it takes its starting point in an ideological position very different to the patriarchal biblical text. Reading 'from left to right' is Clines' slogan for reading the text against its grain and insisting on addressing one's own questions to the text.

In his Cheltenham lecture Clines advocated a pragmatic, pluralist approach to Old Testament hermeneutics in which a range of interpretative methods are available and Old Testament scholars select those they enjoy and find useful. He acknowledges that

It is the question whether feminist criticism and ideological criticism are, properly speaking, interpretational at all. Perhaps we should be sharply distinguishing between acts of interpretation, which seek only to represent the text, to exegete and explicate it, to rehearse it in words other than its own, to understand it-but not to critique or evaluate it-and, on the other hand, acts of criticism, which judge the text by a norm outside itself. If a feminist or some other ideological point of criticism takes its point of departure from an ethical or ideological position that lies outside the text, one which may indeed be deeply hostile to the text, its goal cannot be mere understanding, mere interpretation... 
Will not the most interesting prospects for biblical studies lie precisely in reading against the grain of the texts, in bringing to bear on our texts our own cultural and historical and personal positions, and in evaluating the texts against the hundred and one yardsticks that the pluralist world of international biblical scholarship will inevitably suggest?41

An example of this pluralist style in action is his essay 'Reading Esther from Left to Right' in which he performs a formalist, structuralist, feminist, materialist and deconstructionist reading on Esther and concludes:

I have been impressed in this study by the value of using as many strategies as possible for reading a text. As a critic of the text, I should hate to be restricted by a methodological purism. What I have noticed is that different strategies confirm, complement or comment on other strategies, and so help develop an integrated but polychromatic reading. 42

Although his close exegetical work has remained very traditional,43 Clines has shown a refreshing tendency to go against the flow of historical critical Old Testament scholarship. However his ready espousal of hermeneutic pluralism, textual indeterminacy and consumerism raise all sorts of questions which we will address below.

\section{Orientation Amidst the Flux}

That the postmodern turn is being felt in Old Testament studies is obvious from the above. Old Testament studies are fast coming to reflect the crisis that is central to postmodernity. However, as with theories of the postmodern there is no consensus about how to understand this crisis or how to respond to it. John Rogerson suggests that Habermas has much

\footnotetext{
41'Possibilities and Priorities', 86-87.

${ }^{42}$ Reading Esther from Left to Right' in D.J.A. Clines et al. (eds.), The Bible in Three Dimensions. Essays in Celebration of Forty Years of Biblical Studies in the University of Sheffield (Sheffield: JSOT Press, 1990), 31-52. The quotation is from p. 51 .

${ }^{43}$ See, for example, D.J.A. Clines, Job 1-20 (Waco: Word, 1989).
} 
to offer for Old Testament studies. ${ }^{44}$ Clines is more comfortable with Stanley Fish, whereas Brueggemann seeks to resurrect a Kantian understanding of the imagination (see below). John Collins argues that 'historical criticism remains the most satisfactory context for biblical theology', while conceding that 'some of the claims for objectivity of that method are now recognized to be exaggerated.' 45 Postmodernity is deeply pluralistic and this same pluralism is clearly manifesting itself in Old Testament studies.

Rendtorff, as we have seen, underestimates the extent to which the postmodern turn embodies a crisis for modernity and is thus over optimistic about continuity between historical criticism and postmodern hermeneutics. 46 Clines and Brueggemann are the more perceptive analysts of postmodernity in that they see the radical shift that the turn implies in Old Testament studies. Clines embraces methodological pluralism, indeterminacy and the impossibility of validating readings. Brueggemann rejects the possibility of large truth.

However, both seem to me to embrace the postmodern turn too readily. Brueggemann describes the postmodern turn as though it is a given that we have to come to terms with. However, it seems to me that what is being called postmodernity is rather late modernity or as Giddens ${ }^{47}$ calls it 'high modernity' so that there is considerable continuity between modernity and 'postmodernity'. In late modernity it has become clear that reason is never going to lead us to new certainties, and so we are left with change and flux with no hope of new immutables. 48 Human autonomy, that central

44J. Rogerson, 'What Does it Mean to be Human? The Central Question of Old Testament Theology?' in The Bible in Three Dimensions, 285-298.

45J. Collins, 'Is a Critical Biblical Theology possible?', in W.H. Propp et al. (eds.), The Hebrew Bible and its Interpreters (Indiana: Eisenbrauns, 1990) 117. The quotation is from p. 15.

46In a somewhat similar way Perdue, The Collapse of History, welcomes the shift while trying to hold on to universal criteria for legitimating readings, thereby manifesting a superficial understanding of the extent to which postmodern pluralism undermines rationalism.

${ }^{47} \mathrm{~A}$. Giddens, Modernity and Self-Identity. Self and Society in the Late Modern Age (Cambridge: Polity, 1990).

48See Harvey, The Condition of Postmodernity. 
plank of modernity, remains however, firmly in place. Human reason or emotion may not be the source of absolute truth, but courageously we will learn to live with and even celebrate our limitations. A distinguishing feature of modernity is its rejection of Christ, 49 and postmodernism shows few signs of becoming genuinely post-modern in recovering a sense of transcendence. This type of analysis seems to me closer to the reality of what we are experiencing: the inner tensions and contradictions of modernity are playing themselves out in the open, but this is not post-modernity in my view.

Thus Brueggemann overstates the hiatus between modernity and postmodernity and dismisses 'more-than-local' truth too quickly. To say that all knowledge is contextual and local, and large truth cannot be voiced, as Brueggemann does, is to position oneself where one can see the whole and thus make such a comprehensive statement. In other words Brueggemann's description of postmodernity conceals a powerful, autonomous metanarrative. 50 And as Hart notes, Brueggemann's own position contradicts his description of our new epistemological context. Brueggemann acknowledges that creation/fall/redemption is the core drama of the Bible, and he clearly wants an ethically charged imagination and not a nihilistic postmodern one. Especially when one looks at Brueggemann's critique of consumerism it is apparent how strongly he critiques this element of postmodernism from a Christian perspective. As Hart notes, 'what we have... is a very clear appeal to one specific "grand story"... and an attempt to privilege it lock, stock, and barrel over the decaying consumerist perspective of modernity. 51

This contradiction in Brueggemann and postmodernism in general alerts us to the fact that some form of a

\footnotetext{
${ }^{49}$ See C. Gunton, The One, the Three and the Many. God, Creation and the Culture of Modernity (Cambridge: CUP, 1993). On p. 1 Gunton quotes William Morris' statement that 'Modernism began and continues wherever civilisation began and continues to deny Christ.'

${ }^{50} \mathrm{Cf}$. T. Hart, '(Probably) the Greatest Story Ever Told? Reflections On Brueggemann's The Bible and Post-Modern Imagination', in A.N.S. Lane (ed.), Interpreting the Bible (Leicester: Apollos, 1997) 181-204. On p. 182 he speaks of 'the now familiar grand narrative of post-modernity'.

51Hart, 'Probably', 191-92.
} 
metanarrative is inescapable. Rather than denying the validity of metanarratives and thereby becoming the unconscious victim of one, I suggest that what Old Testament scholars need to explore is what sort(s) of metanarrative is (are) appropriate to Old Testament study. Immediately this is done philosophical and religious questions surface. There is a general failure, however, to explore the postmodern turn at the foundational/ philosophical level ${ }^{52}$ and to probe the relationship between religion and metanarrative.

In this respect the very different ways in which Clines and Brueggemann have embraced postmodernity are significant. It is broadly recognised now that one aspect of postmodernity is the encroachment of the capitalist consumer motif upon all areas of life. 53 Clines, as we have seen, embraces this aspect of postmodernity and allows it to reshape the practice and theory of Old Testament hermeneutics. The methods and the product of Old Testament interpretation are to be determined by consumer desire. By contrast, Brueggemann is repeatedly at pains to distance himself from consumerism. 54 In his section on the development of an evangelical infrastructure that will shape interpretation he writes:

if this evangelical infrastructure is not carefully constructed, the Christian congregation will rely on the dominant infrastructure of consumerism, and will not even discern until very late (too late) that the infrastructure of consumerism contains little good news. 55

It is I think a mistake to reconstruct Old Testament hermeneutics along consumer lines. Clines' espousal of indeterminacy, which opens the door for his consumer move, sounds radical, but, as Norris and Bertens have noted, is politically close to the right wing pragmatism of scholars like

52For the argument that philosophically postmodernism represents a foundational crisis see Bartholomew, 'Post/Late? Modernity', 31-32.

53See D. Lyon, Postmodernity (Buckingham: Open University Press, 1994) 54-69.

54The Bible and Post-Modern Imagination, 27, 29, 40, 57.

${ }^{55}$ The Bible and Post-Modern Imagination, 27. 
Rorty. The debate about the death of the author seems to have come full circle. Bertens notes that

Deriddean postmodernism largely limited itself to texts and intertexts. In its firm belief that the attack on representation was itself an important political act, it was content to celebrate the so-called death of the subject... without realizing that the end of representation had paradoxically made questions of subjectivity and authorship... all the more relevant... In the absence of transcendent truth it matters, more than ever, who is speaking (or writing), and why, and to whom. 56

Clines' espousal of consumerism and indeterminacy is vulnerable to Christopher Norris's critique:

\begin{abstract}
'theory' as practised by post-structuralists, post-modernists and other fashionable figures on the current intellectual scene... their 'radicalism' has now passed over into a species of disguised apologetics for the socio-political status quo, a persuasion that 'reality' is constituted through and through by the meanings, values or discourses that presently compose it, so that nothing could count as effective counter-argument, much less a critique of existing institutions on valid theoretical grounds. 57
\end{abstract}

There is, in fact, a tension in Clines' work between doing what sells and his concern for ideological critique. Personal desire underlies both but in the light of his consumer hermeneutic, it is hard to see how Clines would ground the sort of feminist and political critique that he favours. The latter generally rest on arguing that texts really are patriarchal or whatever, arguments which are undermined by Clines' view of textual indeterminacy and doing what will sell.

Both Brueggemann and Clines accept postmodern epistemological pluralism but do so in different ways. Clines' is a pragmatic pluralism in which a variety of methodologies are

${ }^{56} \mathrm{H}$. Bertens, The Idea of the Postmodern (London and New York: Routledge, 1995) 7.

${ }^{57}$ C. Norris, What's Wrong With Postmodernism? (London: Harvester Wheatsheaf, 1990) 3-4. 
available and interpreters use what works for them. Brueggemann acknowledges the plurality of hermeneutics but argues for a hermeneutic which is shaped by faith and privileges imagination as the key to knowledge in the local context. In his appeal to an evangelical infrastructure, he leans on the grand story of the gospel, as Hart notes. 58 His privileging of imagination and the powers he assigns to it also contradict his espousal of pluralism but in a somewhat different way. And this productive understanding of the imagination has been subjected to radical critique in postmodernity. ${ }^{59}$ As Kearney says,

Right across the spectrum of structuralist, post-structuralist and deconstructionist thinking, one notes a common concern to dismantle the very notion of imagination... The philosophical category of imagination, like that of 'man' himself, appears to be dissolving into an anonymous play of language. 60

Thus, for Brueggemann to sustain his proposed hermeneutic, he would need to take a far more critical stance in relation to postmodern thinking. Hart rightly says of Brueggemann's book that ' $[t]$ he inconsistencies... seem more likely to be the result of not having crossed the Rubicon at all: paddling instead in the shallows on the near side, admiring the views across the water, yet from a viewpoint afforded by more familiar ground. ${ }^{\prime} 1$

Recently Brueggemann gave a lecture entitled 'Meaning as Wounded and Haunted' at a Canadian conference on postmodernism and biblical interpretation. ${ }^{62}$ Rather than letting each small text speak in all its roughness, Brueggemann invoked Ricoeur in support of reading suspiciously and then practising a strategy of retrieval. Clearly some larger narrative

58Hart, 'Probably', 191-92.

${ }^{59} \mathrm{On}$ postmodern imagination see Kearney, The Wake of Imagination, 251358. Brueggemann's stress on the variety of worlds that can be imagined out of the pieces the Bible provides leans more towards the pluralism of postmodernism. See Hart, 'Probably', 198-201, 204 for a critique of the confusions in Brueggemann's understanding of the role of imagination.

60Kearney, The Wake of Imagination, 251.

61Hart, 'Probably', 189.

62The conference was entitled 'Trust and Suspicion' and was held at the Institute for Christian Studies in Toronto from 21-23 May 1997. 
is operating in such a hermeneutic, which confirms the contradictions in Brueggemann's espousal of postmodernism. 63

On the surface Clines' pluralism would appear to be more democratic, but this is not necessarily so. In his Cheltenham lecture on the supermarket of methods Clines dealt with new criticism, rhetorical criticism, structuralism, feminist criticism, materialist or political criticism, psychoanalytical criticism, reader response criticism and deconstruction. Conspicuous by its absence was any type of religious (Christian or Jewish) reading of the Old Testament, which suggests a certain imperialism in his pluralism.64 Such imperialism manifests itself in much contemporary Old Testament hermeneutic pluralism. Mark Brett, in his work on Child's canonical approach, argues for a pluralistic understanding of Old Testament hermeneutics and acknowledges the validity of the canonical approach provided it be seen as one of a variety of methodologies, precisely what Childs denies.65 Similarly John Barton argues for a pluralism of approaches to Old Testament texts provided one does not think that there is a correct way to read such texts. 66

This sort of liberal pluralism indicates that it is hard and perhaps impossible to escape some type of metanarrative and thus some type of unified Old Testament hermeneutic. Certainly there is a need for a more sophisticated analysis of pluralism in Old Testament studies. What is called hermeneutic pluralism often amounts to a consideration of different aspects of the hermeneutic process. Thus feminist readings are often not 'readings' but critiques of patriarchal ideology in texts which first have to be read before the feminist critique can take place. Lategan points out that what is called historical criticism focuses on part of the communication act involved in

63See Hart, 'Probably', 201-204 for other instances of contradiction.

${ }^{64}$ Clines does include a Christian reading of Job in his Word commentary and he has written the commentary on Job for the overtly Christian New Bible Commentary. 21st Century Edition. However his recent writings fail to mention such readings as a priority.

${ }^{65} \mathrm{M}$. Brett, Biblical Criticism in Crisis? The Impact of the Canonical Approach on Old Testament Studies (Cambridge: CUP, 1991).

66J. Barton, Reading the Old Testament. Method in Biblical Study (London: DLT, 1984). 
interpreting a text, namely the relationship between the sender and the text. 67 The new literary criticism by comparison focuses on the text itself and reader response criticism on the role of the reader in interpretation. Clearly historical criticism, 'textual criticism' and reader criticism are not necessarily antithetical, but could form part of a hermeneutic seeking to interpret texts as part of a communicative act.

However, hermeneutic pluralism also refers to the interpretation of the Old Testament from conflicting ideological/religious/philosophical perspectives. Clouser has recently argued that religious beliefs are universal and are the deepest type of human belief which shape all of our lives, including our theorising. ${ }^{68}$ And using insights from Polanyi Hart rightly notes that while all products of human knowing are perspectival, we indwell a particular perspective because it seems to us the best and most complete key to reality. ${ }^{69}$ The nature of the Christian story is that at its centre is one who claims to be the clue to reality, and for all the fallibility of our constructions we dare not fail to witness to Christ as that clue.

At its best the postmodern context provides us with an opportunity to take that religious shaping seriously. ${ }^{70}$ In terms of religion Brueggemann and Clines' hermeneutic proposals represent two distinct postmodern approaches. As Barton reluctantly acknowledges and as the contributors in Braaten and Jensen advocate, $a$ hermeneutic response to postmodernism is to advocate a religiously shaped hermeneutic. ${ }^{71}$ To a significant extent Brueggemann represents this approach. Barton prefers an objective, scientific approach which overlaps

67B. Lategan, 'Hermeneutics', in D.N. Freedman et al. (eds.), Anchor Bible Dictionary (New York: Doubleday, 1992) III.149-54.

68R. Clouser, The Myth of Religious Neutrality. An Essay on the Hidden Role of Religious Beliefs in Theories (London: University of Notre Dame Press, 1991).

${ }^{69}$ Hart, 'Probably', 196-98.

${ }^{70}$ See K. Flanagan, 'Introduction', in K. Flanagan \& P.C. Jupp (eds.), Postmodernity, Sociology and Religion (London: Macmillan, 1996) 1-13

71J. Barton, The Future of Old Testament Study (Oxford: Clarendon, 1993); C.E. Braaten \& R.W. Jensen (eds.), Reclaiming the Bible for the Church (Edinburgh: T. \& T. Clark, 1995). 
with Clines' secular, late-modern approach in their suspicion of a religiously shaped hermeneutic.

Personally I agree with Hart that faith in the Lord Christ demands that we relate that faith to all of life including biblical hermeneutics. And indeed, the hermeneutic proposals of Brueggemann, Lindbeck, Frei, Childs, Newbigin, Sternberg and Lategan offer a diversity of fruitful ways forward in the development of a what Ouweneel calls a bibliotropic hermeneutic, i.e., one shaped by a Christian perspective upon reality which does justice to the historical, literary and kerygmatic aspects of Old Testament texts as well as the contextual nature of interpretation. ${ }^{72}$ Since this will be developed in the context of the Christian community, as Brueggemann stresses, it will certainly not achieve universal agreement but then the goal of universal public knowledge is no longer credible, as I think Alisdair MacIntyre has demonstrated. ${ }^{73}$

For Old Testament scholarship postmodernity means that all practitioners will have to reflect on and give an account of their foundational/philosophical presuppositions, and surely we ought to promote a pluralism in the academy which makes room for such critical analysis. In this way the pluralism in Old Testament studies will become clear. Clines and Brueggemann are two examples of different ways of grounding Old Testament studies philosophically. Although I am cautious of Brueggemann's too ready acceptance of all truth as local and his privileging of imagination, I do think that his path is the more helpful one. In the context of postmodern pluralism it seeks to formulate an integrated Christian/theological hermeneutic which will allow the Bible to speak as God's Word. This does justice to the perspectival nature of truth claims (following MacIntyre) while keeping open claims of universal relevance within that perspective.

\footnotetext{
72W.J. Ouweneel, A Critical Analysis of the External and Internal Prolegomena of Systematic Theology (South Africa: Unpublished D.Th. thesis, University of the Orange Free State).

${ }^{73}$ See A. MacIntyre, Whose Justice? Which Rationality? (London: Duckworth, 1988).
} 